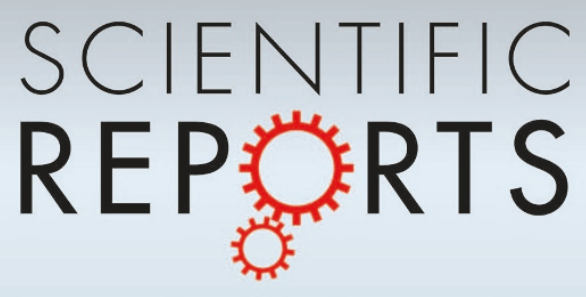

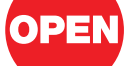

SUBJECT AREAS:

TECTONICS

ENVIRONMENTAL ECONOMICS

GEODYNAMICS

ASTRONOMY AND PLANETARY SCIENCE

Received

9 October 2012

Accepted

28 November 2012

Published

13 December 2012

Correspondence and requests for materials should be addressed to M.C. (marco.cuffaro@ igag.cnr.it) or C.D.

(carlo.doglioni@ uniromal.it)

\section{The tectonic puzzle of the Messina area (Southern ltaly): Insights from new seismic reflection data}

\author{
Carlo Doglioni' ${ }^{1}$ Marco Ligi ${ }^{2}$, Davide Scrocca ${ }^{3}$, Sabina Bigi i, 3 , Giovanni Bortoluzzi ${ }^{2}$, Eugenio Carminati ${ }^{1}$, \\ Marco Cuffaro ${ }^{3}$, Filippo D'Oriano ${ }^{2}$, Vittoria Forleo', Filippo Muccini ${ }^{4} \&$ Federica Riguzzi $^{5}$
}

'Dipartimento di Scienze della Terra, Università Sapienza, P.le A. Moro 5, 00185 Roma, Italy, ${ }^{2}$ Istituto di Scienze Marine, CNR, U.O.S di Bologna, Via Gobetti 101, 40129 Bologna, Italy, ${ }^{3}$ sttituto di Geologia Ambientale e Geoingegneria, CNR, c/o Dipartimento di Scienze della Terra, Università Sapienza, P.le A. Moro 5, 00185 Roma, Italy, ${ }^{4}$ Istituto Nazionale di Geofisica e Vulcanologia, Roma2, Via Pezzino Basso 2, 19020, Fezzano (La Spezia), Italy, Istituto Nazionale di Geofisica e Vulcanologia, Roma, Via di Vigna Murata, 605, 00143 Rome, Italy.

The Messina Strait, that separates peninsular Italy from Sicily, is one of the most seismically active areas of the Mediterranean. The structure and seismotectonic setting of the region are poorly understood, although the area is highly populated and important infrastructures are planned there. New seismic reflection data have identified a number of faults, as well as a crustal scale NE-trending anticline few $\mathrm{km}$ north of the strait. These features are interpreted as due to active right-lateral transpression along the north-eastern Sicilian offshore, coexisting with extensional and right-lateral transtensional tectonics in the southern Messina Strait. This complex tectonic network appears to be controlled by independent and overlapping tectonic settings, due to the presence of a diffuse transfer zone between the SE-ward retreating Calabria subduction zone relative to slab advance in the western Sicilian side.

he Messina Strait and surrounding area are seismically active and responsible for the $M_{w} 7.1$ December $28^{\text {th }}$ 1908 earthquake ${ }^{1,2}$, with a related tsunami (run-up height up to $10 \mathrm{~m}$ ), which caused more than 60.000 casualties. Several earthquakes have struck the area over the centuries ${ }^{1-4}$. The area is highly populated and the longest single span ever built bridge has been planned to cross the Messina Strait (Fig. 1). In order to contribute to the understanding of the tectonic framework, we explored the area by a multichannel seismic reflection and multibeam survey (TIR10, cruise report available at http://www.ismar.cnr.it). A morphologic map and regional cross sections, based on these new data, allow us to image the upper 3-4 km of the crust of the area (Figs. 2, 3 and 4), adding information for the evaluation of the seismic risk in the area.

The Messina Strait is an extensional feature, crosscutting the Apennines belt, and separating the Italian peninsula from Sicily (Fig. 1). It is located in the area between the Neogene Tyrrhenian backarc basin, developed in the hangingwall of the Apennines, and the Mesozoic-Paleogene Ionian basin, which is the foreland and the area of propagation of the Neogene to present Apennines thin-skinned accretionary prism ${ }^{5,6}$. The Messina Strait is part of the transitional zone separating the faster SE-retreating slab beneath Calabria and the Sicilian continental lithosphere ${ }^{7-9}$. The main transition runs along the northward prolongation of the Malta Escarpment (west of the Messina Strait), that separates Calabria to the east, moving SE-ward relative to Sardinia (Eurasia), whereas to the west of the escarpment, the Sicilian microplate converges NW-ward with respect to Sardinia ${ }^{10}$. This different behaviour is marked particularly by the subduction hinge which is moving away with respect to the upper plate (i.e., Sardinia) along the Calabrian side, whereas it converges relative to Sardinia in the Sicilian side of the subduction zone ${ }^{11}$. This is coherent with the contractional setting in the northern Sicilian offshore ${ }^{12,13}$. The Messina Strait is shaped by a complex network of normal and transtensional transfer faults ${ }^{14-18}$ (Fig. 1 and Fig. 2), that may have a multiple origin: 1) extension associated with the back-arc spreading, contemporaneous and genetically linked to the Apennines slab retreat; 2) mantle wedging and uplift of the Apennines belt; 3) faster differential SE-ward retreat of the Calabrian slab relative to the Sicilian slab; 4) lengthening of the Apennines arc associated to the radial slab retreat. The Strait is located on the upper plate crust, that is $\sim 26 \mathrm{~km} \mathrm{thick}^{19}$, and composed by a stack of Alpine and Hercynian metamorphic basement slices overlain by OligoMiocene terrigenous sequences, SE-thrust on non-metamorphic Meso-Cenozoic sedimentary successions ${ }^{14,20}$. A Miocene-Quaternary marine sequence rests unconformably on this complex and is similar across the two sides 


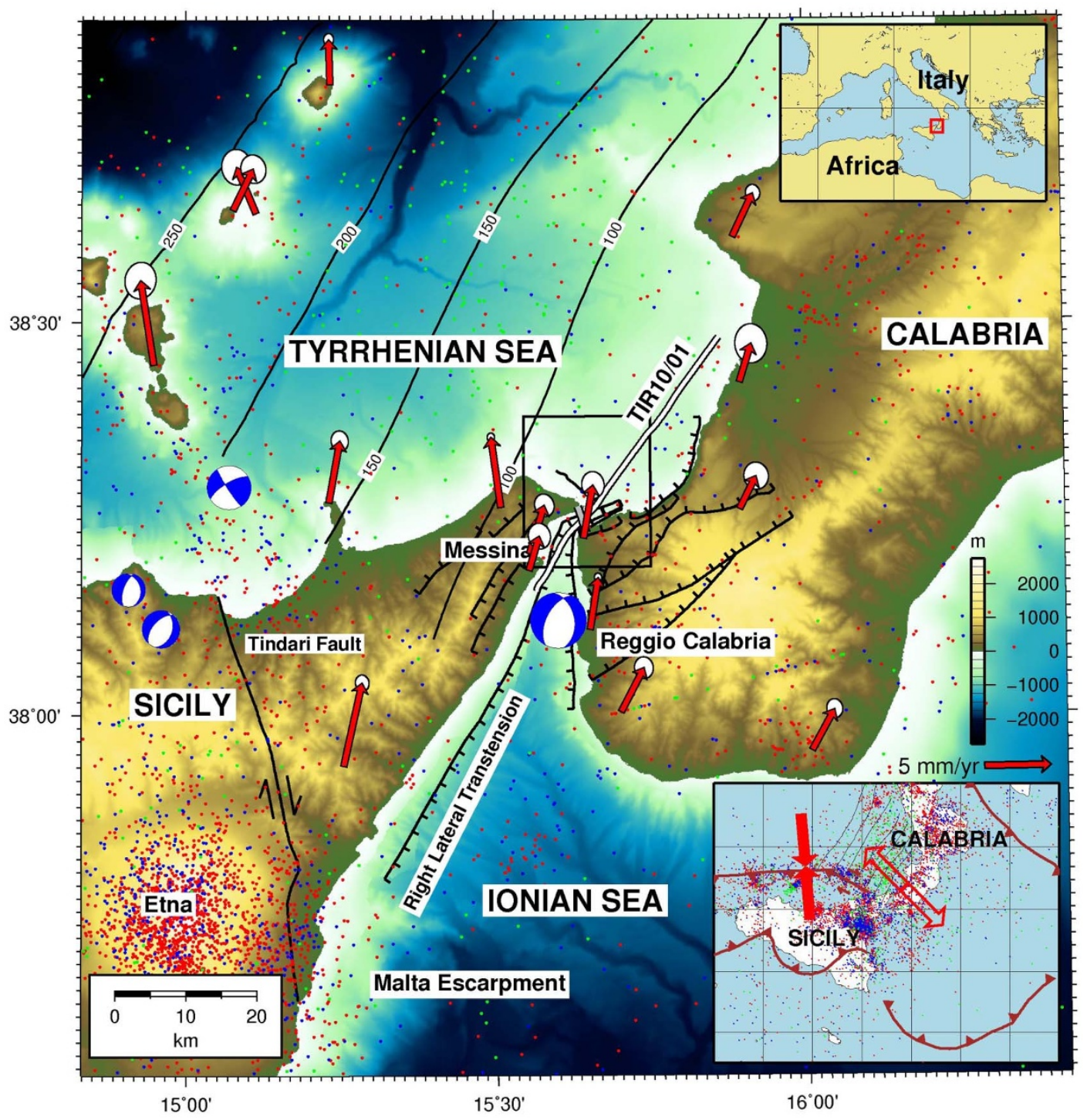

Figure 1 Geological setting of the Messina Strait, with location of the planned bridge (gray solid line), and of the seismic reflection profile TIR10/01 (white line). This area is shaped by a complex network of normal and transtensional faults (black lines with ticks). Depth of the top of the subducted Ionian slab (ref. 38 and references therein) is also shown (black lines). Red, blue and green dots are earthquake epicentres ${ }^{38}$, occurring at depths $<15 \mathrm{~km}$, between 15 and $35 \mathrm{~km}$, and $>35 \mathrm{~km}$, respectively (http://csi.rm.ingv.it). Focal plane solutions are from ref. 39. Red arrows indicate GPS velocity vectors ${ }^{10}$. Black rectangle is the survey area of Fig. 2. Lower-right panel shows a tectonic sketch of the southern Tyrrhenian Sea, representing coexisting compression (solid red arrows) along the northeastern Sicilian offshore, and extension (open red arrows) in southern Calabria.

of the Strait, although thickness variations occur from Calabria to Sicily. In Calabria it includes $\sim 300 \mathrm{~m}$ of Tortonian sandstones and clays and Lower Pliocene marls (Trubi Formation), unconformably covered by i) Upper Pliocene-Lower Pleistocene marine clays and sands (40-150 m thick ${ }^{20}$ ); ii) Middle-Upper Pleistocene marine clays, calcarenites and calcareous sands, $\sim 100 \mathrm{~m}$ thick ${ }^{20}$. The Pleistocene Messina sands and conglomerates (200-400 m thick) lie unconformably both on the thrust sheets and on the MiocenePleistocene sequence. These deposits contain Gilbert fan deltas ${ }^{21}$, prograding toward the Messina Strait from the Calabrian and the Sicilian coasts, indicating that they were deposited into an already opened graben, pre-dating it. They have been correlated to the uplift processes affecting the flanks of the Strait in the last 0.7-1 Ma (0.5$1.2 \mathrm{~mm} / \mathrm{yr}$, ref. 24).

The occurrence of large active faults has been inferred based on the uplift of the Pleistocene marine terraces along the coast of the Strait, where five to twelve orders of different age terraces have been identified ${ }^{17,22,23}$. Uplift was faster in the Calabrian sector, where normal faults show evidence of recent activity. In particular, along the Sicilian coast, close to Messina, the MIS 5.5 terrace (about $125 \mathrm{kyr}$ ) is located at $90 \mathrm{~m}$ a.s.l., while in the Villa San Giovanni area (on the Calabrian coast) it is uplifted up to $170 \mathrm{~m}$ a.s.1. ${ }^{24}$. In Supplementary Fig. S1 are shown the average uplift rates inferred from the MIS 5.5 terrace. The differential uplift implies active tectonics in the Strait. The morphology of the north-eastern part of the strait depicts an ENE-trending graben, although deep geometries indicate an asymmetric feature. The recent faults in the area are arranged in two broad $\sim$ ENE-trending arrays with opposing polarity separated by a NW-trending transfer zone located between Messina and Reggio Calabria ${ }^{24,25}$. Moving southward, the Strait trends more N-S, and kinematically a right-lateral transtensional component is expected as proposed by ref. 26 and supported by the present GPS data. This is consistent with the faster SE-ward retreat of the Apennines-Calabrian subduction with respect to Sicily ${ }^{11}$, which implies a right-lateral transtension in between. 


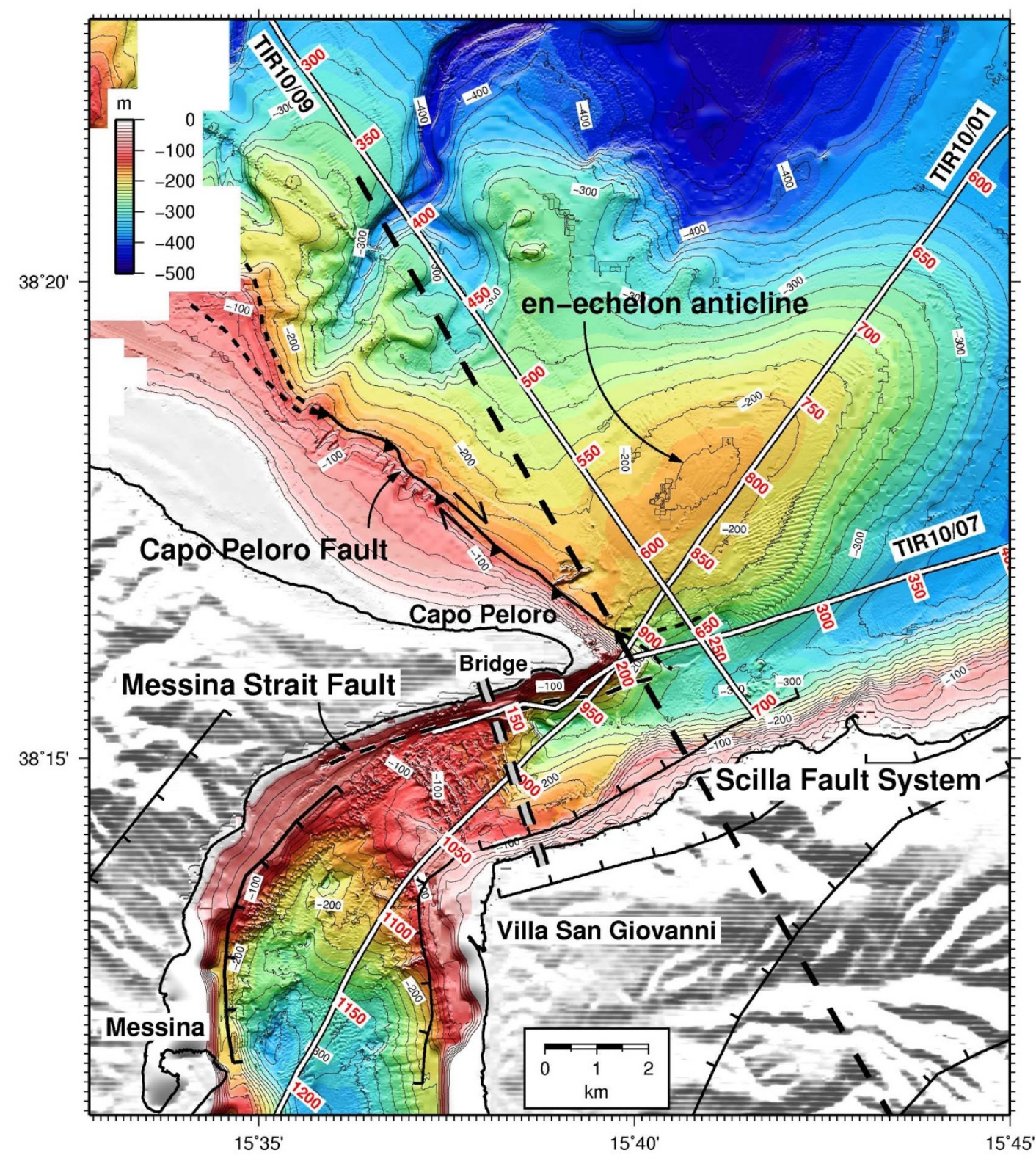

Figure $2 \mid$ Morpho-structural map of the Messina Strait, with location of the scarp of the Capo Peloro fault, of the blind Messina Strait Fault (dashed black line), and of the Scilla Fault System. The adjacent anticline to the north is located at the eastern tip line of the Capo Peloro fault. The fold axis to the northeast is en-échelon with respect to the E-W-trending right-lateral transpression offshore northern Sicily, and slightly en-échelon with respect to the Capo Peloro fault. The white lines indicate locations of seismic profiles, with shot points, TIR10/01, TIR10/07 and TIR10/09 (Figs. 3 and 4, Supplementary Figs. S2, S8, S9 and S10). The thick grey and black dashed lines indicate the planned bridge and the cross section shown in Fig. 6, respectively.

\section{Results}

The seismic section of Fig. 3 shows an indistinct basement (Hercynian metamorphic rocks and possibly Mesozoic cover, overprinted by Alpine deformation) and a Pliocene-Pleistocene sedimentary sequence (mostly siliciclastic) covering a widespread unconformity that can be ascribed to the Messinian sea-level drop ${ }^{27}$. The entire Plio-Pleistocene sequence is cross cut by a major fault, the Capo Peloro fault, with an offset of the basement top of about $325 \mathrm{~ms}$ TWT, that assuming an interval velocity for the Plio-Pleistocene units in the 1700-2000 m/s range (Supplementary Tab. S1), is equivalent to a minimum displacement of $\sim 275-325 \mathrm{~m}$ (Fig. 4 and Supplementary Fig. S2). Since the time of onset of the fault activity is not constrained, a minimum conservative vertical displacement rate of $0.05-0.06 \mathrm{~mm} / \mathrm{yr}$ can be estimated, assuming a Pliocene age for the sediments above the displaced basement. However, the seafloor is significantly shaped and offset by the Capo Peloro fault and the adjacent anticline (Fig. 2), suggesting activity, possibly with higher displacement rates. The Capo Peloro fault dips steeply to the SSW, and its geometry suggests both reverse and strike-slip components. However the horizontal component is unconstrained, but it could be represented by the shortening accommodated by the anticline to the northeast of the Capo Peloro fault (Fig. 3) which is accounting for a shortening $>500 \mathrm{~m}$ when cross-section balanced technique is applied. Both features appear upper Pleistocene in age. Multibeam data allow to trace a reliable NW-prolongation of the Capo Peloro fault (Fig. 2), well constrained by an abrupt escarpment in the bathymetry. With the same data it was possible to reconstruct the map geometry of the anticline to the north of the Capo Peloro fault. The steep attitude of the Capo Peloro fault (Figs. 3, 4 and S2) would indicate a dominant strike-slip component of the Capo Peloro fault. Moreover, even if the horizontal offset is unconstrained, the $\mathrm{N} 115^{\circ}\left( \pm 5^{\circ}\right)$ azimuth of the fault, and the $\mathrm{N} 45^{\circ}\left( \pm 5^{\circ}\right)$ azimuth of the 


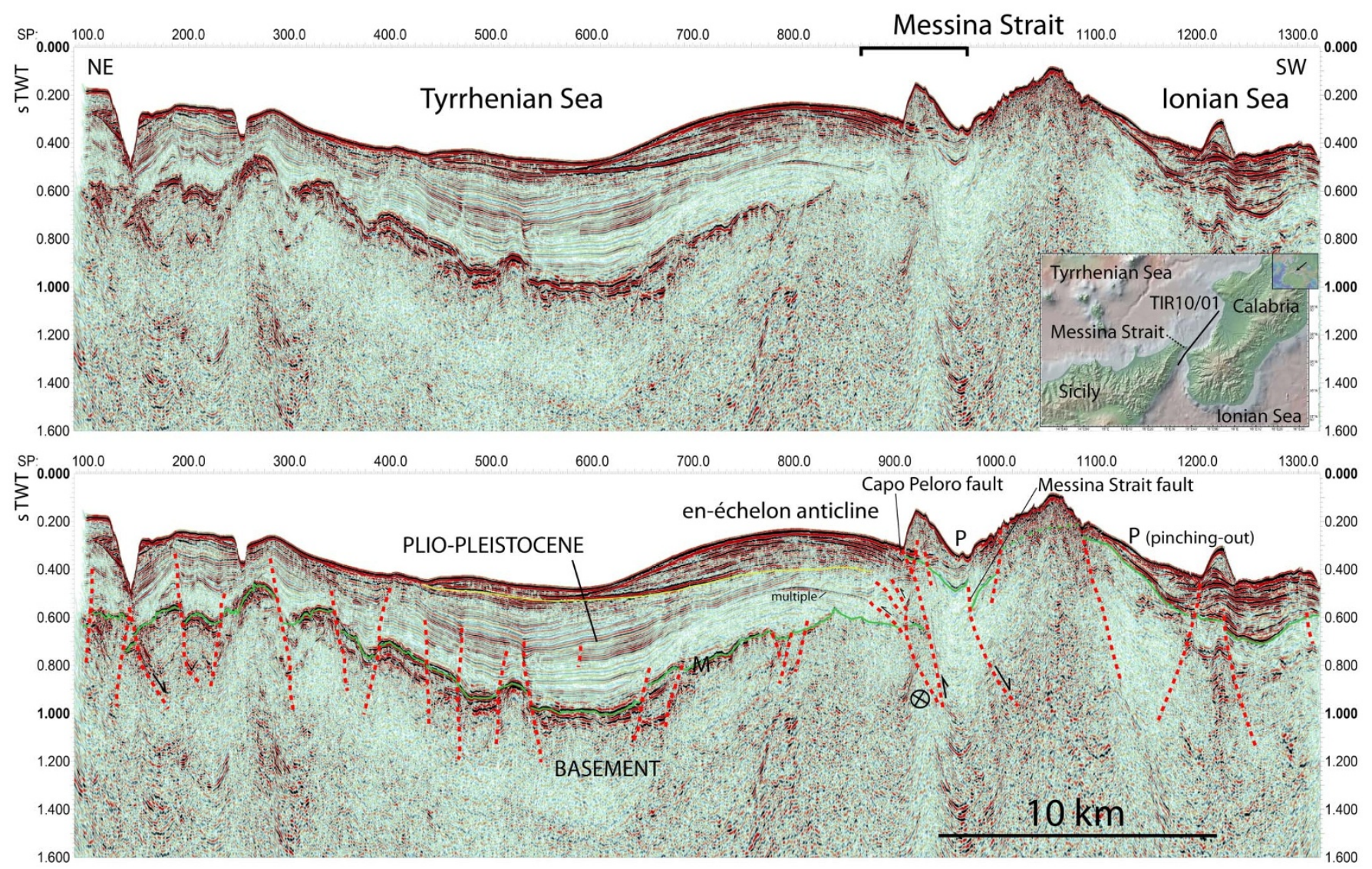

Figure 3 High resolutions pre-stack time migrated seismic reflection profile TIR10/01 (top: uninterpreted; bottom: interpreted). Moving from the left side (NE), there are two canyons cutting into the Plio-Pleistocene sequence. The Messinian unconformity (green solid line, M) covers an undifferentiated and tectonized basement (Hercynian and Alpine metamorphic rocks, Mesozoic passive margin and Cenozoic active margin sequences). The Messinian strong reflectors are inferred as evaporites which pinch-out and possibly disappear toward the southwest. The yellow line is an intra Pleistocene unconformity. In the central part of the section a crustal scale anticline actively deforms the seafloor and the whole underlying sequence. The Capo Peloro fault is inferred as active, since it offsets the seafloor, and based on the steep attitude and the regional context, it is inferred as right-lateral transpressive fault. The Messina Strait is sitting on top of a normal-fault-propagation syncline determining the morphology of the Strait itself. The Pleistocene sequences show growth geometry, suggesting syntectonic sedimentation all along the cross-section. Therefore, both contractional or transpressive features coexist with tensional faults. Profile location is indicated in Fig. 2. The black line on top of the upper panel marks the portion of profile TIR10/01 shown in Fig. S10.

anticline (Fig. 2) are consistent with a right lateral transpressioncompression, coherent with the present-day stress field in the Northern Sicily offshore ${ }^{12,28}$. The $12-\mathrm{km}$-wide anticline deforms and uplifts the seafloor and is adjacent to the north of the Capo Peloro fault. The anticline deforms also the Messinian unconformity and the underlying "basement", hence disproving a sedimentaryrelated mound origin of the bombing (Fig. 3). The sedimentary sequence overlying the "basement" high of the anticline, shows seismic attributes and thickness ( $400 \mathrm{~ms}$, TWT) similar to those of the basin to the northeast (left). Therefore, the geometry of reflectors cannot be related to a velocity pull-up, supporting an anticlinerelated uplift. Morever, the sea-floor is deformed according to the underlying structure, again supporting a tectonic origin of the bathymetric swell. The normal faults in the syncline are located within the syncline depocenter and they could have been steepened by the contractional setting. However, one of the results of this research is that the extension and contraction operated contemporaneously in the same area, albeit of different orientation. The width of the anticline implies a minimum depth of its decoupling equal to its width, i.e., the upper crust. Both the Capo Peloro fault and the anticline have the requisites to be considered active transpressionrelated features. In fact they have the same age, and the anticline is located at the eastern tip of the strike slip fault, suggesting being co-genetic. The fold strikes at about $70^{\circ}$ with respect to the Capo Peloro fault, being not exactly en-échelon to it. However the fault is SW-dipping and having a transpressive component, the expected en-échelon angle can be higher than a pure strike-slip fault. It is a single anticline (at least the only one mapped so far), but it is a crustal scale fold and the associated fault is possibly not long enough to generate more than one major fold, and only at its termination. In case of co-genetic relation between the Capo Peloro fault and the adjacent anticline located at its tip line, the shortening adsorbed by the anticline should represent the horizontal offset of the Capo Peloro fault. In fact the Capo Peloro fault terminates eastward where the anticline developed, being the tip line the transfer zone among the fault and the fold (Fig. 2). GPS data predict dominant extension in the area where the anticline is located ${ }^{29}$, but this is probably due to the biased geodetic analysis lacking of GPS stations at sea (Supplementary Fig. S3). In fact, the anticline is associated to thrusting affecting the seafloor (Fig. 5).

We infer a transpressional component of the Capo Peloro fault because of its SW-ward dip. This is constrained by the offset of the Messinian unconformity in Figs. 3 and 4. Basement metamorphic rocks outcrop inland to the south of the Capo Peloro fault, covered by Miocene-Pleistocene sandstones. These two are very distinct units 


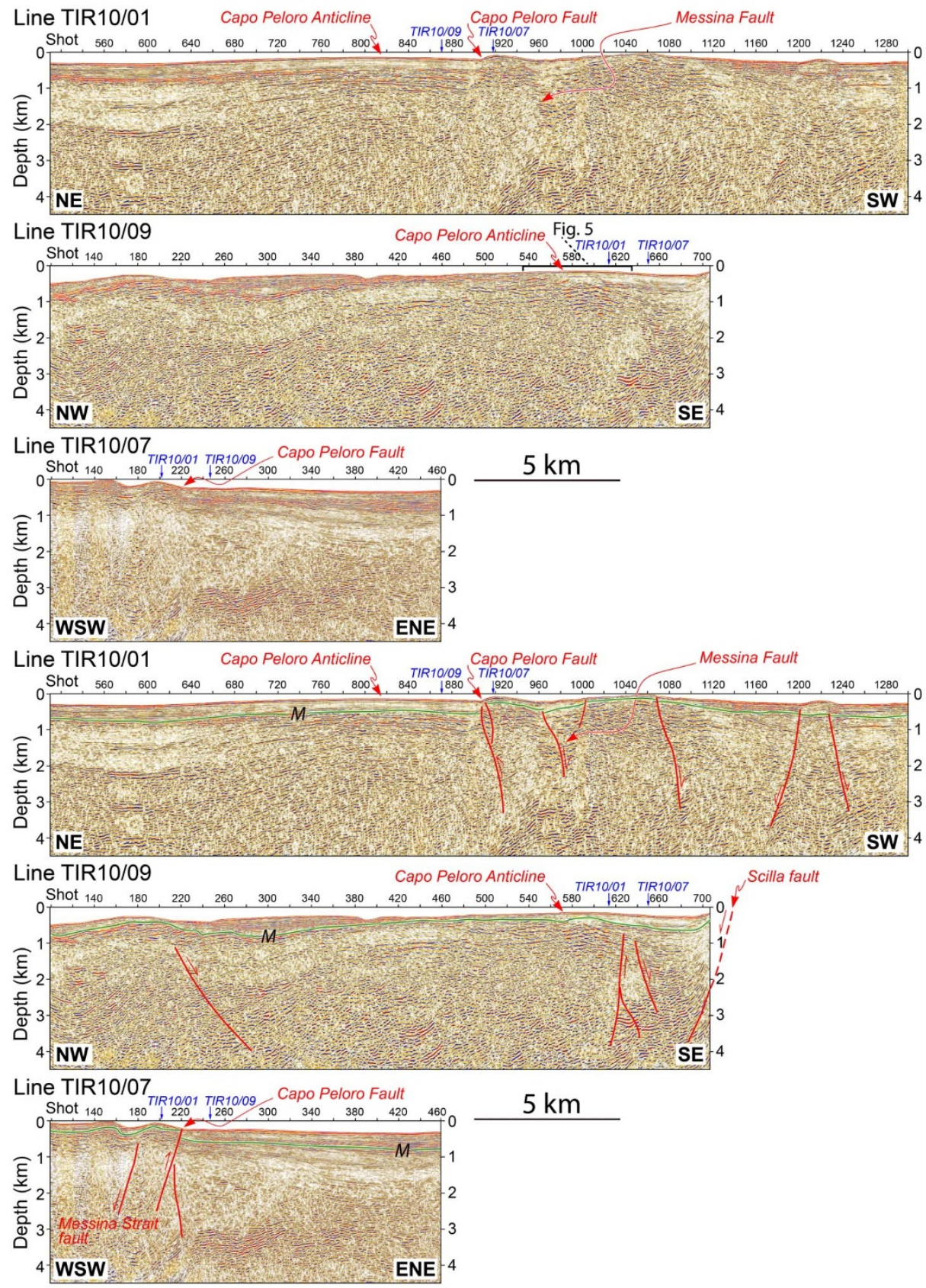

Figure 4 | Post-stack depth migrated seismic profiles TIR10/01 (from shot point 510 to 1300), TIR10/07 and TIR10/09 (top: uninterpreted; bottom: interpreted). The Messinian unconformity $(\mathrm{M})$ is shown by a solid green line. The Plio-Pleistocene sequence rests unconformably on $\mathrm{M}$ and lies above an undifferentiated "basement", ranging from Messinian evaporites down to the metamorphic hercynian or alpine rocks. Notice the coexistence of normal faults, the Capo Peloro reverse fault, and the adjacent anticline. Location of the profiles is in Fig. 2. The black line on top of the upper panel marks the portion of profile TIR10/09 shown in Fig. 5.

that can be easily distinguished in the footwall and hangingwall of the Capo Peloro fault in the seismic profile. Therefore the same rocks must be located at depth below the unconformity, which is at about $0.6 \mathrm{~s}$ in Fig. 3 to the north of the Capo Peloro fault. Right-lateral transpression offshore all northern Sicily is documented by seismicity and previous regional geological and GPS studies ${ }^{12}$. Moreover, the linear surface trace of the Capo Peloro fault, the absence of a recognizable associate fault-propagation fold in the hangingwall, and the high angle trace of the fault, point to a transpressional component. A blind normal fault is interpreted below the Messina Strait, offsetting the acoustic basement top, and transferred upward to a normal-fault propagation syncline (Figs. 3 and 4). This type of structures does not need to emerge and cross-cut the sea-floor, since the normal fault offset is transferred to the overlying fold $\mathrm{d}^{30,31}$. This fold is also synsedimentary, given that the Pleistocene sequence is pinching out along the flanks of the syncline. Therefore the fault bounding to the NW the Messina Strait does not outcrop, and the surface manifestation is the syncline that characterizes the Strait itself (Fig. 6). Moreover, integrating these data with interpretation of other seismic lines from the TIR10 cruise, the normal fault recognized in the Strait was found to be antithetic to the NW-dipping Scilla normal fault system, located in the Calabrian sector (Figs. 4 and 6), described by ref. 25, who attributed to this fault a cumulative slip rate of $\sim 0.5 \mathrm{~mm} / \mathrm{yr}$, with coseismic slip of $\sim 1.5-2 \mathrm{~m}$, hinting at the possibility of 6.9-7.0 $\mathrm{M}_{\mathrm{w}}$ earthquakes. The location of the Scilla fault system reported in this paper is the result of the integration of data 
a

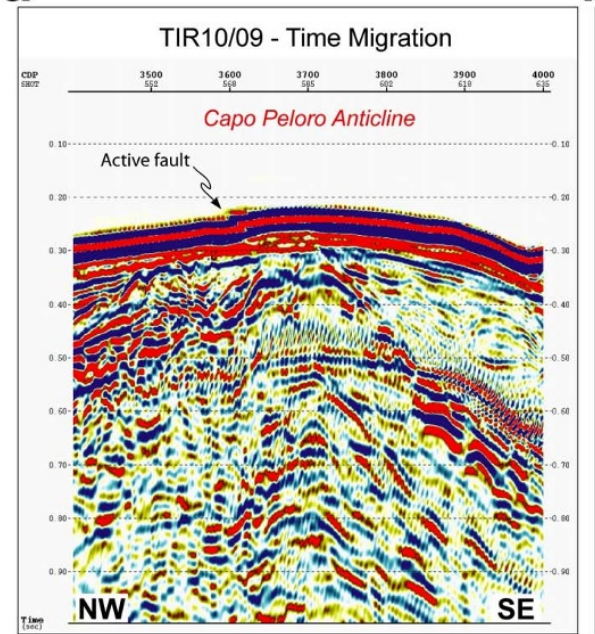

b

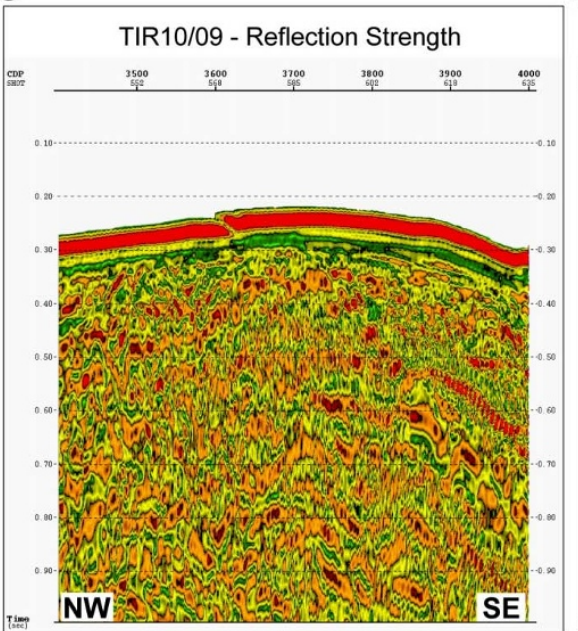

C

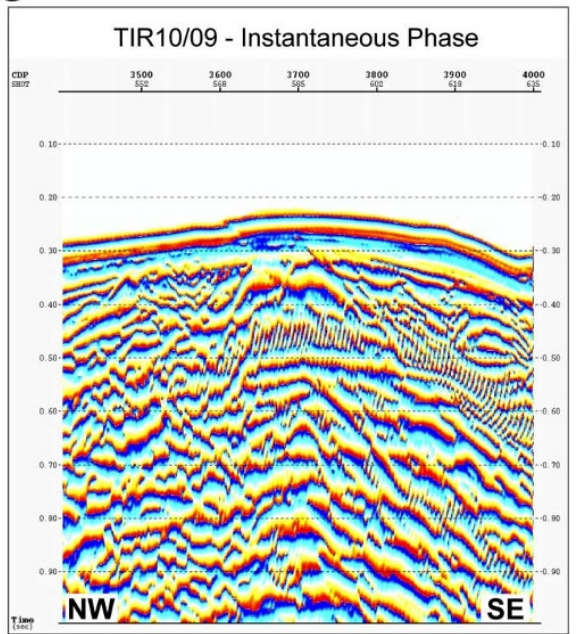

Figure 5 | Close-up and seismic-derived instantaneous attributes of portion of the seismic reflection profile TIR10/09, showing structural details of the Capo Peloro anticline. a, time migration. b, reflection strength. The instantaneous amplitude measures the reflectivity strength which is proportional to the square root of the total energy of the seismic signal at an instant of time. Note the lack of reflection energy just beneath the $\sim 7 \mathrm{~m}$ seafloor step located on the summit of the Capo Peloro anticline. c, instantaneous phase. This seismic attribute emphasizes the continuity of events on a seismic section. Reflection strength, instantaneous phase and seismic section panels show clearly a small thrust cutting the summit of the anticline and offsetting the seafloor, confirming the recent activity of the structure.
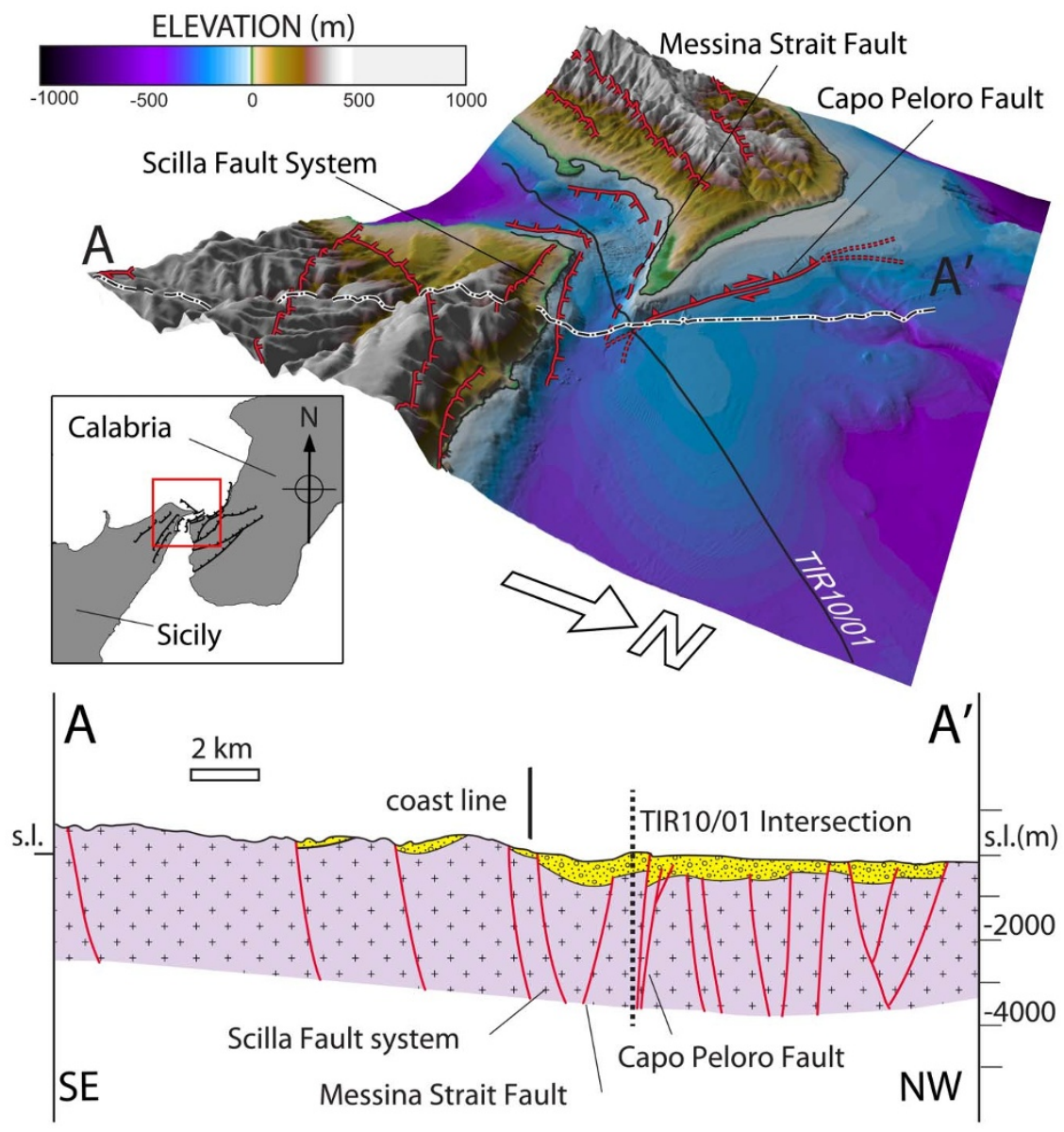

Figure 6 Morpho-bathymetry of the Messina Strait area and cross-section geological interpretation. View from northeast. Bathymetry from Fig. 2. The geological cross section has been obtained from the data of three seismic lines of the TIR10 cruise shown in Fig. 4 (TIR10/01, TIR10/07, TIR10/09), s.l. sea level. All the data were elaborated using Move 2011 (http://www.mve.com/). Notice the normal fault of the Messina Strait gradually transferring to the northeast into the Scilla Fault. The Messina graben is here asymmetric, having a thicker syntectonic sedimentary package in the northwestern margin. The Capo Peloro transpressive fault indicates a different tectonic setting. In few $\mathrm{km}$, two independent and coexisting stress fields act in the same region. 


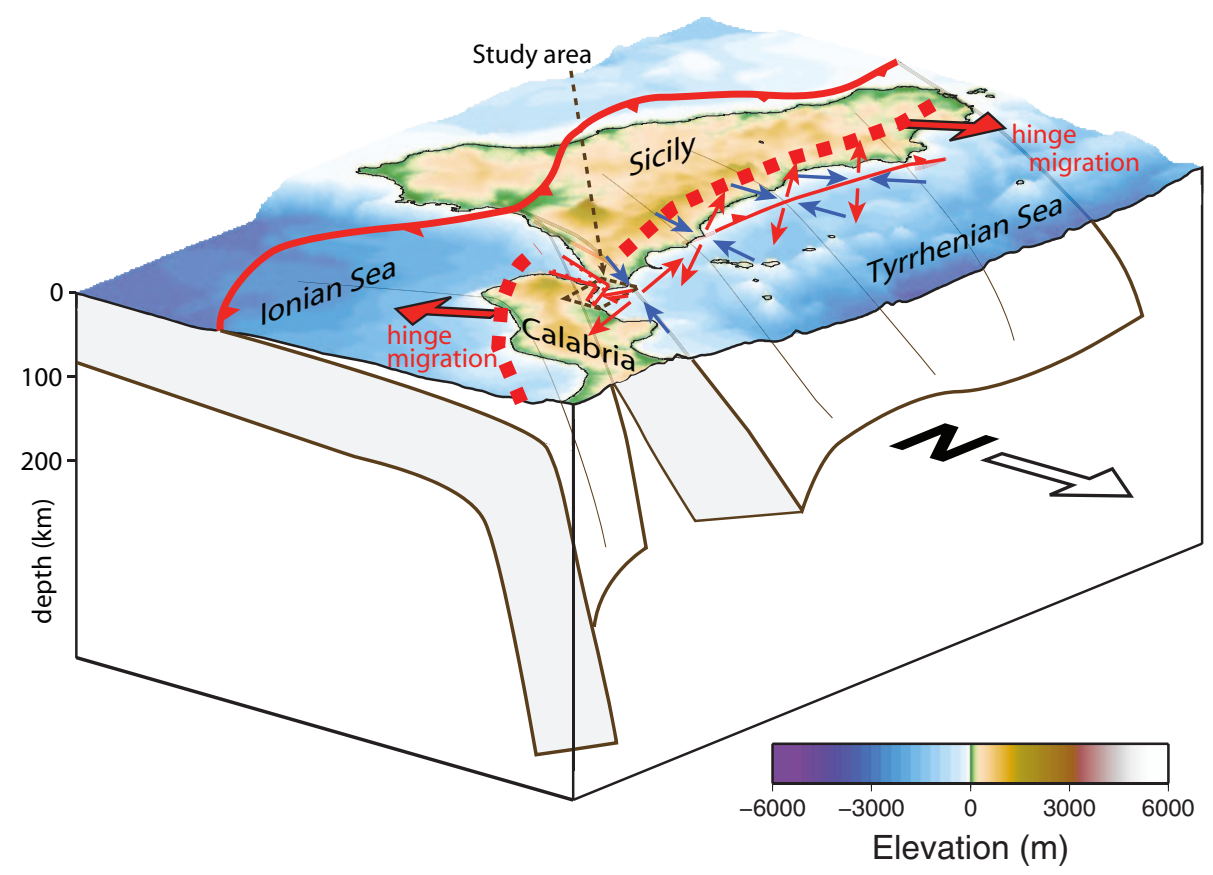

Figure $7 \mid$ Block diagram showing the geometry of the Apennines-Calabrian subduction zone, the differential advancement/retreat of the slab hinge relative to the Sardinia upper plate, in comparison with the Sicilian segment, and the state of stress at the surface. The Messina Strait area is located at the transfer zone where the two tectonic mechanisms partly overlap.

from several geological maps in the area. In the Messina Strait itself, the Messina Strait fault gradually disappears moving NE-ward, whereas the Scilla fault takes over, increasing its importance and offset moving from the Messina Strait to the northeast into Calabria, where it is widely outcropping with a set of subparallel faults. This fault system corresponds to the location of the two sub-parallel and NW-dipping segments mapped in Fig. 6. This pattern is also constrained by the occurrence of different faults in the seismic lines. Finally, several spaced normal or strike-slip faults occur in the north-eastern part of the TIR10/01 section (Fig. 3).

No wells exist in the area to constrain stratigraphy. However, outside the area to the west, there have been a few ODP sites that drilled down into the Messinian ${ }^{32}$. The stratigraphy inferred in this study confirms the reconstruction of ref. 27.

\section{Discussion}

An extensional component of $\sim 65$ nanostrain/yr was estimated from GPS data across the Messina Strait ${ }^{29}$; in addition a horizontal component of shear was detected in the southern part of the Strait ${ }^{33}$. Relative to fixed Eurasia, the sites in Sicily move toward NNW (apart the sites to the east of the Tindari fault, in NE Sicily, the Peloritani Mountains), whereas those in Calabria are NE-trending, at slower rate $^{10}$ (Figs. 1, 2, 6 and Supplementary Fig. S1). This implies a faster northward component of motion of Sicily with respect to Calabria, and E-W stretching between mainland Sicily and Calabria. The mean inter-distance between Messina (MESS) and Villa San Giovanni (VLSG) is $7936.97 \mathrm{~m}$ and remains unchanged within the errors during the time span of GPS measurements (Supplementary Fig. S3) testifying that the significant extension rate detected in the area ${ }^{29}$ is clearly not accommodated within the Strait. The horizontal principal strain rates are not fully constrained by any kind of network since no GPS sites are available SSE of the Calabrian arc; moreover, it is easy to infer erroneous interpretations due to the smoothed effect of the strain rate analysis with respect to the required resolution. Nevertheless, our analysis shows an inner locked Strait with transfer of extension west of it (Supplementary Figs S5a and S5b).
An increased compressive component of the strain rate is detected going southward along the strike of the Strait when the African plate convergence is correctly included in the computation of the strain rate (Supplementary Figs S5c and S5d). In fact, since there are not GPS stations in the Ionian Sea, if that area is not included in the computation of the strain rate, the compression in the southern part of the Messina Strait or eastern Sicily offshore is missing. Assuming a hypothetic site with the angular convergence rate of Africa, then the contraction becomes evident. Therefore, the boundary between Sicily and Calabria is diffuse and is deforming by right-lateral transtension. Most of the right lateral motion and the extensional component appear to be concentrated onshore Sicily, along the northern prolongation of the Malta Escarpment in the central-western part of the Peloritani mountains (e.g., the Tindari fault). The strain rate second invariant, i.e. the cumulative deformation rate of the area (CDR), indicates that the Messina Strait itself is presently not the most actively moving area (Supplementary Fig. S6). In fact, the deformation is distributed over a wide area between $15^{\circ}-16^{\circ} \mathrm{E}$, and $37^{\circ} 30^{\prime}-38^{\circ} 30^{\prime} \mathrm{N}$, and the central part of the Strait shows a local minimum (Supplementary Fig. S6), suggesting tectonic loading, i.e., the faults are locked and the elastic energy is accumulating more than elsewhere, making them more prone to rupture ${ }^{34}$.

When including a SE-ward faster motion of Calabria with respect to Sicily, the southern N-S-trending segment of the Messina Strait is kinematically constrained as a right-lateral transtensional setting; moving into the Ionian Sea, the Messina Strait faults merge into the Malta Escarpment (Supplementary Fig. S7). This last NNWtrending feature acts as the major right-lateral transfer zone between the faster SE-ward retreat of the Ionian slab with respect to Sicily ${ }^{26}$. In the northern Messina Strait, a NE-trending segment of the strait should rather be undergoing pure extension; however the northeastern-most segment of the strait is rather ENE-trending, and it should be instead characterized by some left-lateral transtensional component.

The new seismic reflection profiles identified both transpressional and normal faults cross-cutting the entire visible upper crust (Figs. 3, 4 and Supplementary Fig. S8). Very few of them are confined in the 
Plio-Pleistocene sequence and detached at the Messinian layer. The seismic profile of Fig. 3 does not allow to adequately recognizing the crustal structure beneath the Messinian unconformity. However we infer that the faults should be brittle down to the middle of the crust $(\sim 13 \mathrm{~km})$. In this area the crust is in fact about $26 \mathrm{~km}$ thick, and the brittle-ductile transition is usually recognized at about half of the crustal thickness. If the length of the Messina Strait fault is assumed to be equal to that of the surface graben, a fault surface of about $10 \times 12 \mathrm{~km}$ (assuming $1 \mathrm{~km}$ of surface syncline) can be evaluated. A longer fault (if it is not segmented), dipping eastward beneath Calabria, can be expected along the N-S trend of the southern prolongation of the Messina Strait, where a right-lateral transtensional movement can be inferred.

Based on conservative estimates of the overall dimension (at least $18-20 \mathrm{~km}$ ) and coseismic slip (e.g., $1 \mathrm{~m}$, according to ref. 35) of the transpressional Capo Peloro fault, a magnitude $\left(\mathrm{M}_{\mathrm{w}}\right)$ of at least 6.5 could be expected. However, since the actual northwestward prolongation of this fault cannot be evaluated with the present available data, a magnitude also higher (possibly greater than the magnitude 7.1 associated to the 1908 Messina earthquake) cannot be ruled out.

Active tectonics are controlled by the transfer zone of the Apennines subduction, being the study area located at the transition between the retreating Calabrian slab hinge with respect to the converging hinge of the Sicilian segment relative to the Sardinia upper plate (Fig. 7) as demonstrated also by GPS analysis ${ }^{11}$. Owing to a lateral change in the nature of the subducting plate (from continental, Sicily, to oceanic, Calabria), the slab is laterally teared and characterized by two different geodynamic settings: 1) slab retreat relative to the upper plate in the Calabrian part, inducing NW-SE extension in the Tyrrhenian backarc; 2) convergence relative to the upper plate in the Sicilian part where the NNW AfricaEurope convergence prevails on the slab retreat, with consequent compression-transpression in the Sicily northern offshore (Fig. 7). The Messina Strait, displaying coexistence of extension and dextral transtension, adjacent to an area of transpression along the Capo Peloro fault, is the complicated transfer zone between these two geodynamic settings.

\section{Methods}

Multibeam bathymetry. Bathymetry was acquired during the $2010 \mathrm{R} / \mathrm{V}$ Urania (TIR10, http://www.ismar.cnr.it) cruise with an EM710 Kongsberg-Simrad multibeam, DGPS positioning, and SEAPTH MRU and gyrocompass. Data processed by the Kongsberg Neptune package produced digital terrain models of the area with up to $5 \mathrm{~m}$ of grid resolution. Topography of the Messina Strait was obtained from a synthesis of ISMAR and our own multibeam and single-beam and multibeam data of Italian Navy Hydrographic Institute, and elevation data from the Shuttle Radar Topography Mission database (http://srtm.usgs.gov).

Seismic reflection. Multichannel reflection seismic lines were acquired during TIR10 in the frame of the Italian CROP Project (http://www.crop.cnr.it). The seismic source was a tuned array of 3 GI-GUN $\left(2 \times 45 / 45,75 / 75 \mathrm{in}^{3}\right)$, towed at $5 \mathrm{~m}$ depth, pressure 140 bars. The data were acquired by a SERCEL digital streamer, 96 channels, and $12.5 \mathrm{~m}$ group-interval, towed at 4-7 m depth. Sampling rate was $0.5 \mathrm{~ms}$, with a record length of $12 \mathrm{~s}$, SEG-D storage format on disk, while shot interval was set at $37.5 \mathrm{~m}$. Seismic data have been processed using an industrial package (Disco/Focus) by Paradigm Geophysical, following a standard sequence up to time migration. Additional sequences were applied (a) to remove bottom surface multiples using $2 \mathrm{D}$ SRME technique and adaptive filters, (b) to attenuate random and coherent noise, by filtering in the common shot, offset, receiver domains as well as $\mathrm{f}-\mathrm{k}$ and tau-p domains, (c) to iteratively refine the Velocity Model used for NMO and migration; and (d) to perform pre-stack time migration. Pre-stack-migration was performed in order to achieve high resolution imaging of the shallow part of the profile TIR10/01. In fact, water depth and acquisition parameters enabled good stacking velocity picking only within the Plio-Pleistocene sequence. Furthermore, additional velocity constraints are missing within the survey area. Kirchhoff pre stack time migration was applied to CMP gathers after multiple attenuation adopting a velocity model, obtained iteratively starting from smoothed interval velocities estimated by Dix's formula from stacking velocities. The velocity model was then adjusted at each iteration in order to maximize seismic resolution within the Plio-Quaternary sequence. Bottom surface related multiples removal was achieved adopting the SRME (Surface Related Multiple Elimination) technique, a powerful tool aimed at removing all the multiple energy derived from the water interface, and where the recorded data itself are used as a first estimate of the primary wave-field. The SRME algorithm generates a pre-stack multiple model that can be subtracted from the data using an adaptive subtraction or pattern recognition algorithm. Post-stack depth migration was achieved by a finite difference approximation to the wave equation (MIGZWE) using a velocity model obtained starting from the pre stack time migration model and adjusted iteratively in order to minimize the over/under migration effects at depth (Supplementary Fig. S11).

For the interpretation of the seismic profiles, we started picking the strong reflector (M), which is the key horizon representing the Messinian unconformity (green solid line in Figs 3 and 4). This reflector has been drilled elsewhere by the ODP and represents the strongest acoustic impedance contrast observed in seismic reflection profiles over the entire Mediterranean, being mostly represented by evaporites, which are responsible for the sharp increase of seismic velocity. The unconformity is due to the Messinian sea level drop and related salinity $\mathrm{crisis}^{36}$, and it is an erosional surface in places where evaporites were not deposited. The contact between Plio-Pleistocene sediments and the Messinian unconformity reflect most of the down-going seismic energy, obscuring often the sequence below, in particular when evaporites are present. However, whatever stratigraphic unit lies below the Messinian unconformity, it does not affect neither the interpretation of the geometry of overlying sediment layers, nor the geometry of the faults cutting the entire Plio-Pleistocene sequence. Moreover, evidences of significant decoupling at the level of the Messinian unconformity are missing in this area, given that it represents the backarc basin of the ApenninesTyrrhenian subduction zone.

GPS velocity and strain rate. Velocity and strain analyses are based on GPS velocity solution of the Italian network ${ }^{10}$ (Fig. 1 and Supplementary Fig. S3), freely provided in SINEX format. The velocity field has been estimated simultaneously by a least-squares inversion of all the daily solutions, taking into account only GPS sites with more than 2.5 years of coordinate determinations. The strain rate principal axes have been evaluated by a distance-weighted approach ${ }^{37}$, computed using all stations on a regularly spaced grid $\left(0.1^{\circ} \times 0.1^{\circ}\right)$. The contribution of each station velocity to the strain-rate computed on a given node, is down weighted with the function

$\mathrm{W}=\exp \left(-d^{2} / \alpha^{2}\right)$, where $d$ is the distance between node and station, and $\alpha$ is the smoothing distance parameter (its lowest value is $5 \mathrm{~km}$ ). The algorithm selects the optimal $\alpha$-value from a given a priori interval, depending on the spatial distribution of the GPS sites, consequently strain-rate maps are obtained with spatially variable $\alpha$. Stations located within $1 \alpha$ distance contribute for more than $37 \%$ to the least squares inversion, whereas those at distance greater than $2 \alpha$ contribute for less than $2 \%$. The $2 \mathrm{D}$ second invariant of the strain rate tensor is defined as the scalar $\dot{I}_{2}=\sqrt{\left(\sum_{i j} \dot{\varepsilon}_{i j} \dot{\varepsilon}_{i j}\right)}$ and accounts for all the deformation tensor components, thus representing the cumulative strain rate.

1. Pino, N. A., Piatanesi, A., Valensise, G. \& Boschi, E. The 28 December 1908 Messina Straits earthquake $(\mathrm{M}(\mathrm{w}) 7.1)$ : a great earthquake throughout a century of seismology. Seismol. Res. Lett. 80, 243-259 (2009).

2. Baratta, M. La catastrofe sismica Calabro-Messinese (28 Dicembre 1908), pp 496, Società Geografica Italiana, Roma (1910).

3. Boschi, E., Guidoboni, E., Ferrari, G., Valensise, G. \& Gasperini, P. Catalogo dei Forti Terremoti in Italia dal 461 a.C. al 1990. pp. 644, ING Roma-SGA, Bologna (1997).

4. Billi, A., Funiciello, R., Minelli, L., Faccenna, C., Neri, G., Orecchio, B. \& Presti, D. On the cause of the 1908 Messina tsunami, southern Italy. Geophys. Res. Lett. 35, L06301 (2008).

5. Doglioni, C., Merlini, S. \& Cantarella, G. Foredeep geometries at the front of the Apennines in the Ionian Sea (central Mediterranean). Earth Planet. Sci. Lett. 168, 243-254 (1999)

6. Polonia, A., Torelli, L., Mussoni, P., Gasperini, L., Artoni, A. \& Klaeschen, D. The Calabrian Arc subduction complex in the Ionian Sea: Regional architecture, active deformation, and seismic hazard. Tectonics 30, TC5018 (2011).

7. Doglioni, C. A proposal of kinematic modeling for W-dipping subductions possible applications to the Tyrrhenian-Apennines system. Terra Nova 3 423-434 (1991).

8. Gvirtzman, Z. \& Nur, A. The formation of Mount Etna as the consequence of slab rollback. Nature 401, 782-785 (1999).

9. Govers, R. \& Wortel, M. J. R. Lithosphere tearing at STEP faults: response to edges of subduction zones. Earth Plan. Sci. Lett. 236, 505-523 (2005).

10. Devoti, R., Esposito, A., Pietrantonio, G., Pisani, A. R. \& Riguzzi, F. Evidence of large scale deformation patterns from GPS data in the Italian subduction boundary. Earth Planet. Sci. Lett. 331, 230-241 (2011).

11. Devoti, R., Riguzzi, F., Cuffaro, M. \& Doglioni, C. New GPS constraints on the kinematics of the Apennines subduction. Earth Planet. Sci. Lett. 273, 163-174 (2008).

12. Cuffaro, M., Riguzzi, F., Scrocca, D. \& Doglioni, C. Coexisting tectonic settings: the example of the southern Tyrrhenian Sea. Int. J. Earth Sci. 100, 1915-1924 (2011).

13. Bortoluzzi, G., Ligi, M., Romagnoli, C., Cocchi, L., Casalbore, D., Sgroi, T., Cuffaro, M., Caratori Tontini, F., D’Oriano, F., Ferrante, V., Remia, A. \& Riminuci, F. Interactions between Volcanism and Tectonics in the Western Aeolian Sector, Southern Tyrrhenian Sea. Geophys. J. Int. 183, 64-78 (2010). 
14. Ghisetti, F. Recent deformations and the seismogenic source in the Messina Straits (southern Italy). Tectonophysics 109, 191-208 (1984).

15. Ghisetti, F. Fault parameters in the Messina Strait (southern Italy) and relations with the seismogenic source. Tectonophysics 210, 117-133 (1992).

16. Valensise, G. \& Pantosti, D. A 125 kyr-long geological record of seismic source repeatability: the Messina Straits (southern Italy) and the 1908 earthquake (Ms 7.1/2). Terra Nova 4, 472-483 (1992).

17. Monaco, C. \& Tortorici, L. Active faulting in the Calabrian Arc and eastern Sicily. J. Geodynamics 29, 407-424 (2000).

18. Argnani, A., Brancolini, G., Bonazzi, C., Rovere, M., Accaino, F., Zgur, F. \& Lodolo, E. The results of the Taormina 2006 seismic survey: possible implications for active tectonics in the Messina Straits. Tectonophysics 476, 159-169 (2009).

19. Nicolich, R., Laigle, M., Hirn, A., Cernobori, L. \& Gallart, J. Crustal structure of the Ionian margin of Sicily: Etna volcano in the frame of regional evolution. Tectonophyiscs 329, 121-139 (2000).

20. Lentini, F., Carbone, S., Di Stefano, A. \& Guarneri, P. A multidisciplinary approach to the reconstruction of the Quaternary evolution of the Messina Strait area. In Mapping Geology in Italy (eds Pasquarè, G., Venturini, C. \& Groppelli, G.), 43-50 (APAT, S.El.Ca., Firenze, 2004).

21. Barrier, P. Stratigraphie des depots pliocenes et quaternaries du Detroit de Messine. Documents et Travaux de l' Institut Geologique Albert de Lapparent, Paris 11, 59-81 (1987).

22. Rust, D. \& Kershaw, S. Holocene tectonic uplift patterns in northeastern Sicily: evidence from marine notches in coastal outcrops. Marine Geology 167, 105-126 (2000).

23. Dumas, B., Guérémy, P. \& Raffy, J. Evidence for sea level oscillations by the "characteristic thickness" of marine deposits from raised terraces of Southern Calabria (Italy). Quaternary Science Review 24, 2120-2136 (2005).

24. Antonioli, F., Ferranti, L., Lambeck, K., Kershaw, S., Verrubbi, V. \& Dai Pra, G. Late Pleistocene to Holocene record of changing uplift-rates in southern Calabria and northeastern Sicily (southern Italy, Central Mediterranean Sea). Tectonophysics 422, 23-40 (2006).

25. Ferranti, L., Monaco, C., Morelli, D., Antonioli, F. \& Maschio, L. Holocene activity of the Scilla Fault, Southern Calabria: Insights from coastal morphological and structural investigations. Tectonophysics 453, 74-93 (2008).

26. Doglioni, C., Innocenti, F. \& Mariotti, S. Why Mt. Etna? Terra Nova 13, 25-31 (2001).

27. Fabbri, A., Ghisetti, F. \& Vezzani, L. The Peloritani-Calabria range and the Gioia Basin in the Calabrian Arc (Southern Italy): relationships between land and marine data. Geologica Romana 19, 131-150 (1980).

28. Pepe, F., Bertotti, G. \& Cloething, S. Tectono-stratigraphic modelling of the North Sicily continental margin (southern Tyrrhenian Sea). Tectonophysics 384, 257-273 (2004).

29. Serpelloni, E., Buergmann, R., Anzidei, M., Baldi, P., Ventura, B. M. \& Boschi, E. Strain accumulation across the Messina Straits and kinematics of Sicily and Calabria from GPS data and dislocation modeling. Earth Planet. Sci. Lett. 298, 347-360 (2010).

30. Withjack, M., Olson, J. \& Peterson, E. Experimental models of extensional forced folds. AAPG Bulletin 74, 1038-1054 (1990).

31. Withjack, M. O. \& Callaway, J. S. Active normal faulting beneath a salt layer: an experimental study of deformation in the cover sequence. AAPG Bulletin 84, 627-651 (2000).

32. Kastens, K. A. et al. ODP Leg 107 in the Tyrrhenian Sea: insights into passive margin and back-arc basin evolution. Geol. Soc. Am. Bull 100, 1140-1156 (1988).
33. Anzidei, M., Baldi, P., Bonini, C., Casula, G., Gandolfi, S. \& Riguzzi, F. Geodetic surveys across the Messina Straits (Southern Italy) seismogenetic area. J. Geodynamics 25, 85-97 (1998).

34. Doglioni, C., Barba, S., Carminati, E. \& Riguzzi, F. Role of the brittle-ductile transition on fault activation. Phys. Earth Planet. Int. 184, 160-171 (2011).

35. Wells, D. L. \& Coppersmith, K. J. New empirical relationships among magnitude, rupture length, rupture width, rupture area, and surface displacement, Bull. Seism. Soc. Am 84, 974-1002 (1994).

36. Rouchy, J. M. \& Caruso, A. The Messinian salinity crisis in the Mediterranean basin: A reassessment of the data and an integrated scenario. Sedimentary Geology 188-189, 35-67 (2006).

37. Shen, Z. K., Jackson, D. D. \& Ge, B. X. Crustal deformation across and beyond the Los Angeles basin from geodetic measurements. J. Geophys. Res. 101, 27957-27980 (1996).

38. Chiarabba, C., Jovane, L. \& Di Stefano, R. A new view of Italian seismicity using 20 years of instrumental recordings. Tectonophysics 395, 251-268 (2004).

39. Neri, G., Barberi, G., Oliva, G. \& Orecchio, B. Spatial variations of seismogenic stress orientations in Sicily, south Italy. Phys. Earth Planet. Int. 148, 175-191 (2005).

\section{Acknowledgements}

The comments by David Iacopini greatly improved the article. This research was supported by the Consiglio Nazionale delle Ricerche (CNR) of Italy under the sponsorship of Dipartimento Terra Ambiente. We thank the TIR10 scientific party (G. Buffet, A.M. Conte, A. Milia, M. Pastore, C. Perinelli, and M. Sacchi), Captain V. Lubrano, the officers and the crew of the R/V Urania, and the SOPROMAR for their collaboration during the field-work. ISMAR Bologna and the Navy Hydrographic Institute are warmly acknowledged for sharing bathymetric data. Maps and Digital Terrain Models were produced with the GMT package (http://gmt.soest.hawaii.edu).

\section{Author contributions}

C.D. developed the ideas and the methods for this study and contributed to write the paper. M.C., M.L., D.S. and G.B. led the field work. V.F. and M.L. carried out the seismic data processing. D.S., S.B. and E.C. contributed to the geological interpretations. G.B., M.C., F.D and F.M. took care to data acquisition and multibeam data processing. F.R. carried out the GPS and strain rate analyses. All the authors discussed extensively the results and the interpretations.

\section{Additional information}

Supplementary information accompanies this paper at http://www.nature.com/ scientificreports

Competing financial interests: The authors declare no competing financial interests.

License: This work is licensed under a Creative Commons Attribution-NonCommercial-NoDerivs 3.0 Unported License. To view a copy of this license, visit http://creativecommons.org/licenses/by-nc-nd/3.0/

How to cite this article: Doglioni, C. et al. The tectonic puzzle of the Messina area (Southern Italy): Insights from new seismic reflection data. Sci. Rep. 2, 970; DOI:10.1038/srep00970 (2012) 